Buitrón Sánchez, B.E., Cuen-Romero, F.J., Beresi, M.S., \& Monreal, R. (2021). First record of Ubaghsicystis (Eocrinoidea - Echinodermata) from the Cambrian (Miaolingian, Wuliuan) of Sonora, Mexico: Biostratigraphical and paleoecological considerations. Revista de Biología Tropical, 69(S1), 51-61. DOI 10.15517/rbt.v69iSuppl.1.46326

DOI 10.15517/rbt.v69iSuppl.1.46326

\title{
First record of Ubaghsicystis (Eocrinoidea - Echinodermata) from the Cambrian (Miaolingian, Wuliuan) of Sonora, Mexico: Biostratigraphical and paleoecological considerations
}

\author{
Blanca Estela Buitrón Sánchez ${ }^{1}$ \\ Francisco Javier Cuen-Romero ${ }^{2}$ * \\ Matilde Sylvia Beresi ${ }^{3}$ \\ Rogelio Monreal ${ }^{2}$
}

1. Departamento de Paleontología, Instituto de Geología, Universidad Nacional Autónoma de México, Ciudad Universitaria, México; blancab@unam.mx

2. Departamento de Geología, Universidad de Sonora, Blvd. Luis Encinas y Rosales, Hermosillo, Sonora, México; francisco.cuen@ciencias.uson.mx (*Correspondence).

3. Instituto Argentino de Nivología, Glaciología y Ciencias Ambientales, Consejo Nacional de Investigaciones Científicas y Tecnológicas, Av. A. Ruiz Leal s/n, Parque General San Martín, Mendoza, Argentina; mberesi@mendoza-conicet.gob.ar

Received 25-V-2020. Corrected 07-IX-2020. Accepted 15-IX-2020.

\begin{abstract}
Introduction: The present work constitutes the first record of Ubaghsicystis Gil-Cid \& Domínguez-Alonso (Echinodermata-Eocrinoidea) in the El Gavilán Formation, exposed in the El Sahuaral Hill, a new Cambrian locality of central Sonora, Mexico. The El Gavilán Formation is a sedimentary sequence mainly made up of shale interbedded with limestone, with abundant invertebrate fossils, deposited in an open shelf marine environment. Objective: The main objective of this research work is to describe the species Ubaghsicystis cf. U. segurae for the first time in Mexico, in addition to biostratigraphic and paleoecological considerations. Methods: A composite stratigraphic section of the El Gavilán Fm. was measured in central Sonora, where samples corresponding to eocrinods were collected, the material was examined in the Microscope Leica MZ10. Results: The biotic association is composed of reticulosan sponges, chancelloriids (Chancelloria eros, Allonnia tintinopsis, Archiasterella sp.), hyolithids, brachiopods, trilobites (Quadragnostus depressa, Peronopsis sp., Tonkinella valida, and Elrathina sp.), and echinoderms (Ubaghsicystis cf. U. segurae). Regarding the age, the trilobite association establishes a chronostratigraphic position from the middle Cambrian (Miaolingian, Wuliuan), Altiocculus Subzone, Ehmaniella Zone. The material studied is constituted by isolated echinoderm plates, which probably represent various cycles of theca plates assigned to Ubaghsicystis cf. U. segurae. The genus Ubaghsicystis has been scarcely recorded in a few Cambrian regions (e.g., Burgess Shale in Canada and Los Barrios de Luna in Spain), so that the information about this taxon is limited. Conclusions: The Cambrian succession of Sonora, where Ubaghsicystis occurred, was part of the border from the Laurentia craton during this period, located near the Paleoequator during this period, where ideal conditions for increasing diversity and abundance of species were developed, including echinoderms.
\end{abstract}

Key words: Eocrinoidea; Cambrian; biostratigraphy; paleoecology; Mexico. 
Cambrian sedimentary rocks in Mexico are characterized by being exposed in scarce and isolated outcrops, but having a relatively well-preserved biota, which has been studied since the middle of the last century (Buitrón, 1992). The Cambrian in Sonora is exposed in various isolated locations: Caborca, Cananea, San José de Gracia, Mazatán, and Arivechi. These areas have been studied by several authors (Lochman, 1948; Cooper et al., 1952; Cooper et al., 1956; Stewart, McMenamin, \& Morales-Ramirez, 1984; González-León, 1986; McMenamin, 1987; Almazán-Vázquez, 1989; Vega-Granillo, 1996; Cuen-Romero et al., 2016; Cuen-Romero et al., 2018; Cuen-Romero et al., 2019; Beresi, Buitrón-Sánchez, Cuen-Romero, \& Palafox, 2019). The recent discovery of Cambrian outcrops in central Sonora has been the subject of several stratigraphic and paleontological studies (Nardin, Almazán-Vázquez, \& Buitrón-Sánchez, 2009; Cuen et al., 2013; Buitrón-Sánchez, Corona-González, CuenRomero, Palafox-Reyes, \& Ramírez-Guerrero, 2016; Buitrón-Sánchez, Cuen-Romero, HuertaRuiz, \& Montijo-González, 2017a; BuitrónSánchez, Cuen-Romero, Montijo-González, \& Beresi, 2017b; Cuen-Romero et al., 2016; CuenRomero et al., 2019). This research work was carried out in a new Cambrian locality in the central part of the state of Sonora, El Sahuaral Hill, which has been scarcely studied but has an abundant fossil biota. The first geologic work of the Sahuaral Hill was carried out by Stewart, Amaya-Martínez and Palmer (2002), who mentioned the presence of Cambrian rocks in the area. Danzos-Acuña (2018) and Noriega-Ruiz (2019), carried out a detailed biostratigraphic study of the rocks in the region. However, the first formal work carried out in the area is that by Beresi et al. (2019), who documented the presence of reticulosan sponges and chancellorids. Recently, Noriega-Ruiz et al $(2019 ; 2020)$, carried out a detailed stratigraphic study of the area.

The presence of echinoderms in Mexican Cambrian rocks is scarce, with few isolated elements documented for the country. Nardin et al. (2009) reported isolated plates attributed to the species Gogia granulosa, in the Cambrian section of San José de Gracia, Sonora, Mexico. Similarly, Buitrón-Sánchez et al. (2017b) studied to Gogia granulosa and Gogia sp. from the same area, documenting the paleoecological implications of these species as they are associated with limestone, shale, and sandstone strata, thus, showing great adaptability to different environments.

Regarding eocrinoids, Sprinkle (1973) proposed the new subphylum Blastozoa divided into four classes of extinct Paleozoic "pelmatozoan" echinoderms: Eocrinoidea, Paranlastoidea, Rhombifera, and Blastoidea. Echinoderms of the subphylum Blastozoa are characterized by a group often composed of stalked echinoderms, lacking free arms but with biserial brachioles with nutritional functions, and with the presence of various respiratory structures in the theca. The main objective of this research work is to describe the species Ubaghsicystis cf. U segurae for the first time for Mexico, in addition to biostratigraphic and paleoecological considerations.

\section{MATERIAL AND METHODS}

A composite stratigraphic section of El Gavilán Formation was measured at the southwest flank of El Sahuaral Hill. Samples were collected corresponding to carbonate and detrital rocks. The paleontological material was prepared in the Paleontology Laboratory at the University of Sonora. Due to the conservation of specimens, they do not show contrast when dry, so the samples were wetted. The material was photographed using a Nikon Camera D70S and manipulated with Adobe Photoshop ${ }^{\circledR}$.

Location of the study area: The paleontological material studied comes from El Sahuaral Hill, it is located $44 \mathrm{~km}$ northeast of Hermosillo at geographical coordinates $29^{\circ} 21^{\prime} 5.58^{\prime \prime} \mathrm{N} \& 110^{\circ} 37^{\prime} 13.98^{\prime \prime} \mathrm{W}$, located 7 $\mathrm{km}$ north of the village of San José de Gracia, in the central part of the Sonora state (Fig. 1).

Stratigraphy: Although in the study area, exposed rocks vary in age from Precambrian to 


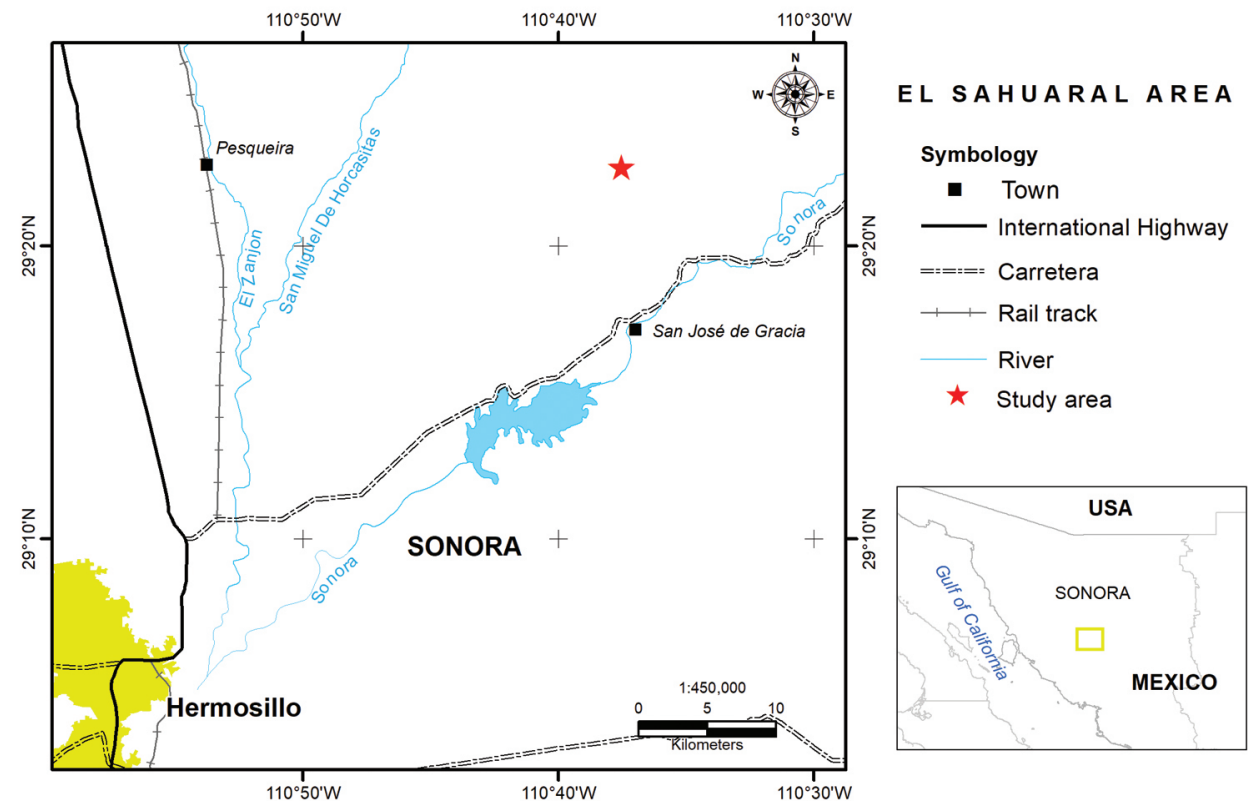

Fig. 1. Location of the study area, northeast of Hermosillo, Sonora, Mexico.

Holocene, the Cambrian rocks are best exposed, and consists of the Proveedora, Buelna, Cerro Prieto, and El Gavilán formations (Fig. 2).

Proveedora Formation: This formation is composed of fine-grained quartzite, with reddish spots due to oxidation, followed by brown to dark gray quartzarenite with the presence of Skolithos isp. This unit is $216 \mathrm{~m}$ thick and is exposed in most of the El Sahuaral Hill (Noriega-Ruiz et al., 2020).

Buelna Formation: This formation is made up of sandy limestone with fragments of hyolithids, followed by limestone with oncolytic algae, ending with dark-colored sandy limestone. In the middle part of the unit, an oolitic limestone bed is present. This unit is exposed at the southwest side of the El Sahuaral Hill with 64 m thickness. The lower and upper contacts are conformable with the Proveedora and Cerro Prieto formations, respectively (NoriegaRuiz et al., 2020).

Cerro Prieto Formation: This formation consists of a cliff-forming dark gray oolitic limestone with evidence of some dolomitization. It is $53 \mathrm{~m}$ thick, being exposed to the southeast side of El Sahuaral Hill. The lower contact is conformable with the Buelna Formation, and the upper contact is conformable with the El Gavilán Formation (Noriega-Ruiz et al., 2020).

El Gavilán Formation: The lower part of this unit is composed of a red-yellow colored thin-bedded shale with reticulosan sponges, chancellorids, brachiopods, and trilobites (Fig. 3 ). The middle part is made up of interbedded red shale and gray limestone beds of varying thickness, with high fossiliferous content. The upper part of the unit consists of yellow sandstone. The real thickness of the unit has not been determined due to folding. Also, this unit is exposed in the valley, southwest of the El Sahuaral Hill. The lower contact is conformable with the Cerro Prieto Formation, while the upper contact is in angular unconformity with the Miocene rhyolite-andesite volcanic rocks (Noriega-Ruiz et al., 2020).

\section{RESULTS}

Systematic paleontology:

The nomenclature and morphological terms used to describe the specimens are those 




Fig. 2. Stratigraphic column of the studied area. Where Sy. $=$ System, Se. $=$ Series, St. $=$ Stage, Th. $=$ Thickness, Fm. $=$ Formation. Modified after Beresi et al. (2019).

proposed by Sprinkle (1973) and Gil-Cid \& Domínguez-Alonso (2002).

Phylum Echinodermata Bruguière, 1791

Subphylum Blastozoa Sprinkle, 1973

Class Eocrinoidea Jaekel, 1918

Family uncertain

Genus Ubaghsicystis

Gil-Cid \& Domínguez-Alonso, 2002

Diagnosis: Eocrinoid with globose theca formed by approximately 40 plates, epispires present in the upper half and absent in the lower part of the theca. Anal pyramid in lateral position above the equator line of the theca. Long, homeomorphic, and holomeric peduncle with a distal fixation disc, the column is of circular section, narrow lumen, and without articular crenulations. Thin, biserial arms, with cover plates and without brachioles (Modified from Gil-Cid \& Domínguez-Alonso, 2002).

Type species: Ubaghsicystis segurae GilCid \& Domínguez-Alonso, 2002

\section{Ubaghsicystis cf. $U$. segurae Fig. 4A-4D}

Occurrence: The El Gavilán Formation, Sahuaral Hill, middle Cambrian (Miaolingian, Wuliuan), Altiocculus Subzone, Ehmaniella Zone.

Material: Two slabs with isolated plates of the specimens USDG 354 and USDG 355. The material is deposited in the Paleontological Collection, Geology Department, University of Sonora, Mexico. 




Fig. 3. Panoramic view of thin-bedded shale from the El Gavilán Formation.

Description: The specimens are incomplete and poorly preserved; only plates from the lower and half part of the theca were recovered. The plates are large of variable diameter, with smooth edges (Table 1).

TABLE 1

Specimens and plate cycles from the specimens studied

\begin{tabular}{|cc}
\hline \multicolumn{2}{c}{ Specimen USDG 354} \\
Plate cycles & Dimensions $(\mathrm{mm})$ \\
$2: 1$ & 7,4 \\
$2: 2$ & 7,3 \\
$3: 2$ & 6,6 \\
$3: 3$ & 6,5 \\
\multicolumn{2}{c}{ Specimen USDG 355 } \\
Plate cycles & Dimensions $(\mathrm{mm})$ \\
$1: 1$ & 4,9 \\
$2: 1$ & 6,4 \\
$2: 2$ & 6,2 \\
$3: 1$ & 4,6 \\
$3: 2$ & 5,0 \\
$4: 2$ & 4,8 \\
$4 ?$ & 4,0 \\
\hline
\end{tabular}

The specimen USDG 354 has four plates, probably corresponds to the infralateral plates of the cycle 2, as they are the largest, with a smooth external surface and sometimes a slight concavity. Over the cycle 2, the cycle of lateral plates (cycle 3) is observed, displaying an irregular and curved polygonal contour. Articulation concavity is observed in plates 2 : 1-2: 2 and 2: 1-3: 2.

The specimen USDG 355 is incomplete and poorly preserved, with seven plates that correspond to 4 cycles. The plates are rounded and smooth-edged. Plate cycle 1 is subrounded. Cycle 2 (infralateral), plates are the largest and have smooth edges, possibly articulated. Cycle 3 (lateral) plates are similar in size to cycle 1 plates but differ in the hexagonal edges $(3: 2)$.

Remarks: The infralateral plates of the theca of the Mexican specimen are very similar to those of Ubaghsicystis segurae, described for the Ovielle Formation from the middle Cambrian of Spain (Gil-Cid \& DomínguezAlonso, 2002), in that they are the largest of 

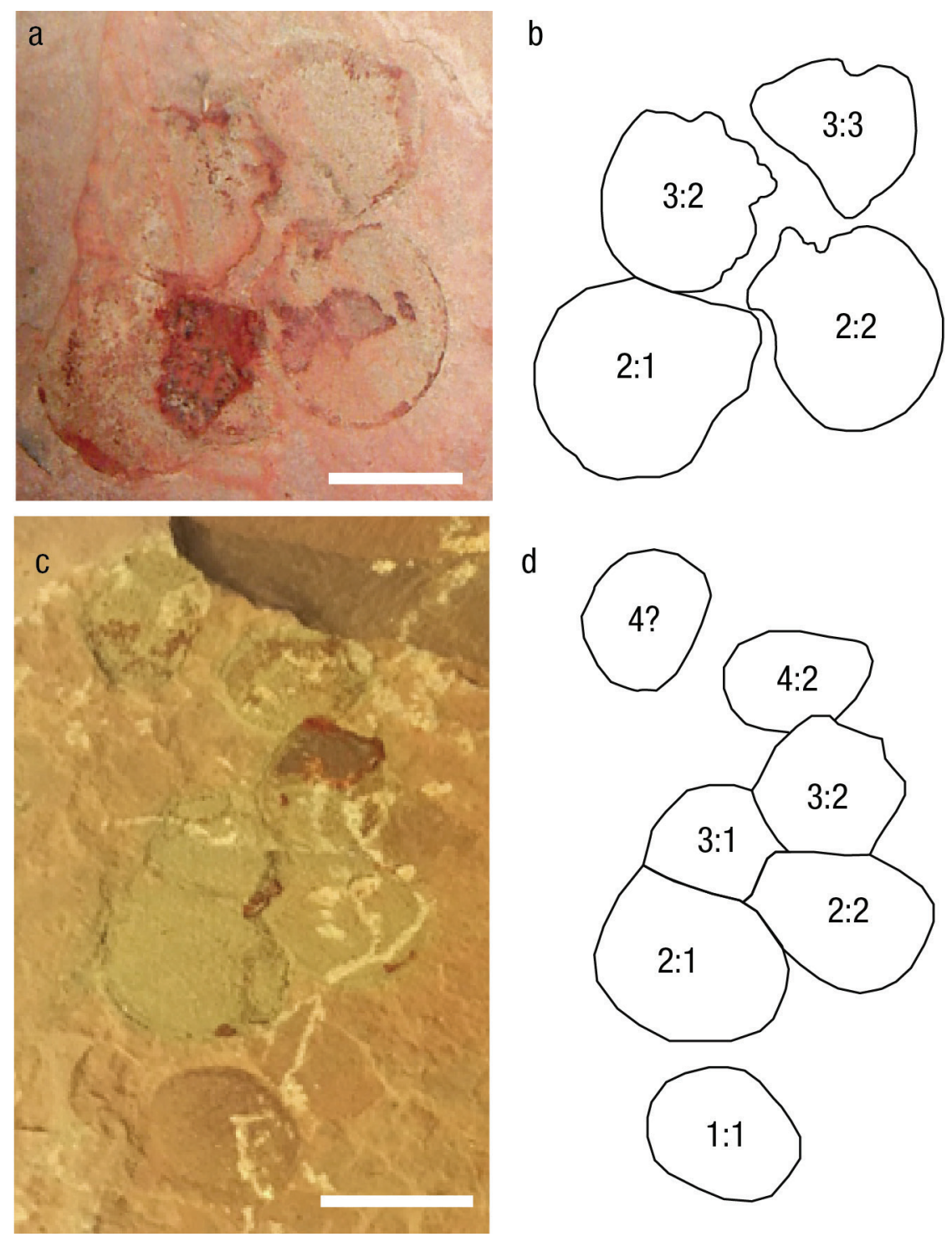

d
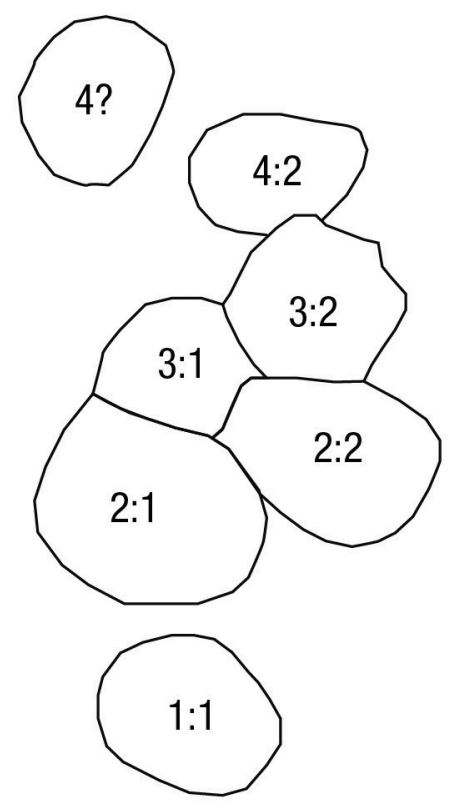

Fig. 4. Isolated plates of Ubaghsicystis cf. U. segura. Scale line $5 \mathrm{~mm}$. A. Specimen USDG 354. B. Specimen USDG 355.

the theca and of smooth surface. The side plates are similar to the same specimens, and they have an irregular polygonal contour, and the $3: 2$ plate is presented in an almost hexagonal shape. For the rest of the plate cycles (4), it is not possible to make a comparison since this cycle in $U$. segurae, is of irregular contour plates without a defined pattern. However, as in the Mexican specimen, they are smaller in size, since they decrease in size as approaching the oral region (Gil-Cid \& Domínguez-Alonso, 2002). A notable difference between the Mexico specimen and the example from Spain is in terms of size, as the plates of the Mexican specimen are considerably larger.

Ubaghsicystis segurae collected in beds of the middle Cambrian area of the High Atlas area of Morocco (Zamora, Clausen, Álvaro, \& Smith, 2010) is similar to the Mexican specimen in the polygonal and surrounded form of 
the plate cycles 2 and 3; however, it differs in its smaller size.

Ubaghsicystis cf. U. segurae from Mexico is very similar to ?Ubaghsicystis sp. from the middle Cambrian Burgess Shale, Canada (Sumrall \& Zamora, 2015), especially in the form of the plate cycles, for which the ones from cycle 2 are also the largest and irregular in size, however in terms of size, is also smaller than the Mexican specimen.

\section{DISCUSSION}

Biostratigraphical considerations: The trilobite fauna from the El Gavilán Formation of the El Sahuaral section is represented by Quadragnostus depressa, Peronopsis sp., Tonkinella valida, and Elrathina antiqua. Altogether, the trilobite fauna indicates a middle Cambrian (Miaolingian, Wuliuan) chronostratigraphic position. The biotic content corresponds to the Altiocculus Subzone, the upper part of the Ehmaniella Zone, defined by Sundberg (1994), as an assemblage zone that occurs above the Glossopleura Zone and below the Bolaspidella Zone, dividing it into four subzones: Proehmaniella, Elrathiella, Ehmaniella, and Altiocculus.

For Gondwana, Ubaghsicystis is known from the Cambrian of Spain and Morocco (GilCid \& Domínguez-Alonso, 2002; Zamora et al., 2010; Sumrall \& Zamora, 2015). In Laurentia, it had only been recorded in the Cambrian of Burgess Shale (Sumrall \& Zamora, 2015), and we are reporting herein the first occurrence of the genus in Mexico. In Spain, Ubaghsicystis segurae has been documented from the Ovielle Formation (Miaolingian, Wuliuan) of Barrios de Luna, Province of León, Northern Spain (GilCid \& Domínguez-Alonso, 2002). In Morocco, it has been studied from the High Atlas, where complete specimens of Ubaghsicystis segurae were recovered, also from the middle Cambrian (Miaolingian, Wuliuan) (Zamora et al., 2010). In North America ?Ubaghsicystis has been documented from the Burgess Shale, Canada, where poorly preserved specimens were recovered, which are included in the
Ehmaniella Zone (syn. Bathyuriscus-Elrathina Rasetti, 1951) of middle Cambrian (Miaolingian-Wuliuan) age. As previously mentioned in Mexico only isolated and disarticulated plates of Ubaghsicystis have been collected from the El Gavilán Formation in the El Sahuaral section, central Sonora, where it is included, in the upper part of the Ehmaniella Zone, middle Cambrian (Miaolingian-Wuliuan).

Paleoecological and paleogeographic considerations: For the study area, an abundant fossil fauna has been documented consisting of reticulosan sponges, chancelloriids, linguloid brachiopods, trilobites (agnostids, ptychopariids, corynexchids), as well as echinoderms. The faunal association constitutes a typical middle Cambrian benthic marine community developed in an open shelf marine environment over a soft substrate. The community of El Sahuaral section is composed of different trophic categories: A) suspension feeders, epifaunal-sessile: Porifera (Protospongia sp., and Diagoniella sp.); Chancelloridae (Chancelloria eros, Allonnia tintinopsis, and Archiasterella sp.); Brachiopoda (Acrothele sp., Prototreta sp., and Dictyonina sp.); Eocrinoidea (Ubaghsicystis). B) Detritus feeders, without vision (slow-moving vagile): Trilobita-Agnostida (Quadragnostus depressa and Peronopsis sp.). C) Detritus feeders, with well-developed vision (fast-moving vagile): Trilobita-Ptychopariida (Elrathina antiqua). D) Carnivorous with welldeveloped vision (fast-moving nektobenthic): Trilobita-Corynexochida (Tonkinella valida). Guilds were established according to the life strategies of different organisms.

The ability of pelmatozoa to adapt to a variety of marine environments was cited by Zamora et al. (2010). Different morphological innovations allowed them to adapt to soft, clay offshore substrates, and sometimes to be able to attach on shell fragments.

As mentioned above, the benthic community of the middle Cambrian of the El Sahuaral was developed in an open shelf marine environment with a soft substrate. This is indicated by the abundance of shale, related to the 


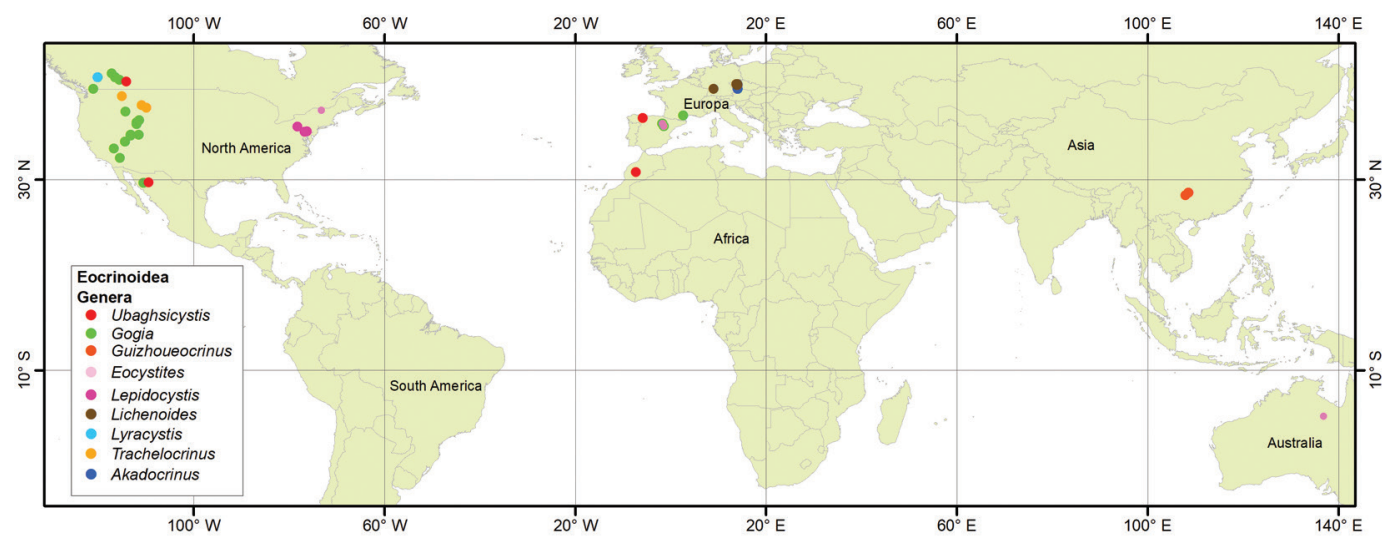

Fig 5. Distribution of common eocrinoids genera in the world: Ubaghsicystis, Gogia, Guizhoueacrinus, Eocystites, Lepidocystis, Lichenoides, Lyracystis, Trachelocrinus, and Akadocrinus.

deposition of clay as fine material, along with the presence of agnostid trilobites (Quadragnostus depressa and Peronopsis sp.), which have only been recorded in open shelf marine environments (Robison, 1976; Liñán, 1996; Cuen-Romero et al., 2019).

Concerning eocrinoids, they had a worldwide paleogeographic distribution during the Cambrian; for example, gogiids have been documented in Spain, France, Morocco, United States, Canada, and Mexico (Nardin et al., 2009; Sumrall \& Zamora, 2015; Buitrón et al., 2017b). In the case of Ubaghsicystis, taking into account the present work, it is known in Morocco, Spain, Canada, and Mexico (Sumrall \& Zamora, 2015) (Fig. 5, Fig. 6).

The fossiliferous assemblage from the middle Cambrian of the El Sahuaral sections consists of complete chancelloriid sclerites and fragments of scleritomes (bodies) partially articulated of Chancelloria eros, together with isolated sclerites belonging to Allonnia tintinopsis, and Archiasterella sp. (Beresi et al., 2019).

In the present report, chancellorids, hyolithids, linguloid brachiopods, and trilobites were also documented. This faunal content is

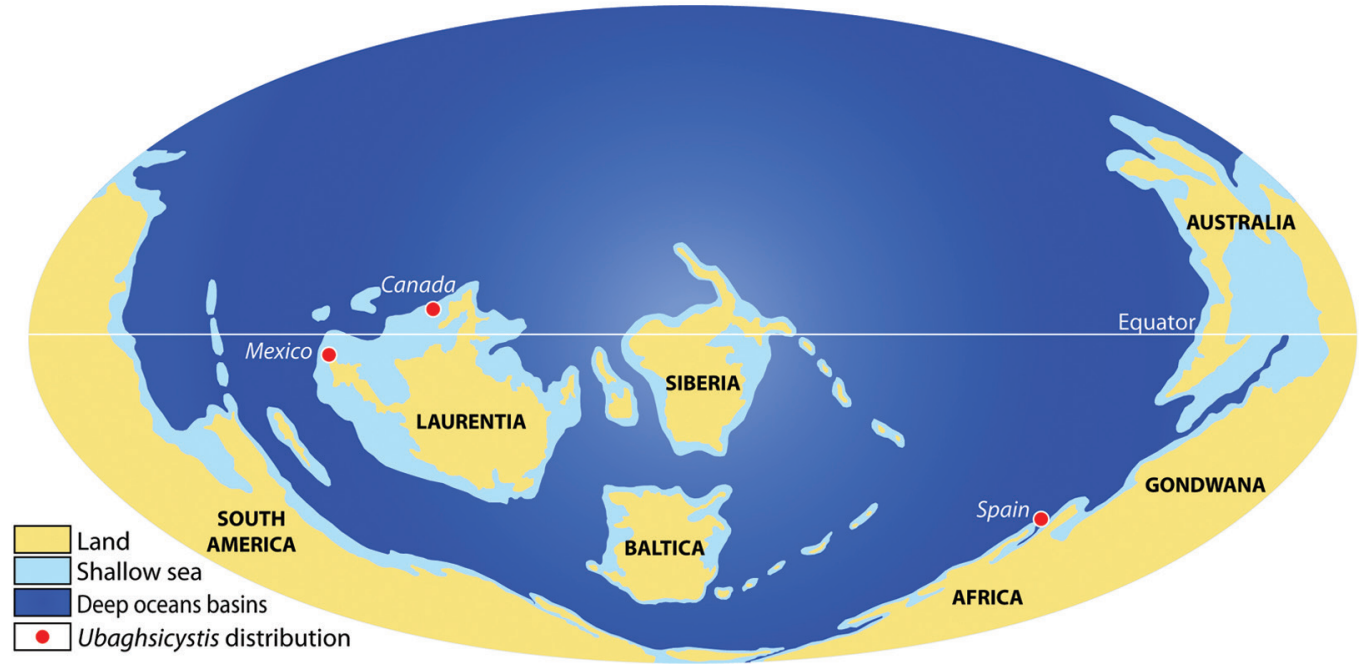

Fig. 6. Paleogeographic distribution of the genus Ubaghsicystis near to the Paleoequator. 
practically identical to the assemblage cited from the type section of San José de Gracia, Sonora, located $10 \mathrm{~km}$ to the south of the study area (Fig. 1) (Cuen et al. 2013; Cuen-Romero et al., 2016).

The El Gavilán Formation has yielded a diverse faunal assemblage including small shelly fossils as Chancelloria, Archiasterella, and Allonnia. Numerous isolated complete chancelloriid sclerites with central rays and 6-7 marginal rays belonging to Chancelloria eros and diverse fragmentary shells of brachiopods dominate most samples. Additionally, eocrinoid remains, few hyolithids, and trilobites are represented in the assemblage. Few conical hyolithids are badly preserved on bedding surfaces. Moreover, some brachiopods as Lingulella sp. Acrothele sp., Prototreta sp., Dictyonina sp., and Linnarsonia sp. were found at the type section of San Jose de Gracia of the El Gavilán Formation (Cuen-Romero et al., 2016), of which some are also present in the El Sahuaral section.

Results demonstrate a wide distribution and palaeobiological importance of the middle Cambrian fauna in Sonora, Mexico as part of the Laurentian shelf, characterized by carbonates deposited in shallow and deeper shelf areas under tropical conditions.

Ethical statement: authors declare that they all agree with this publication and made significant contributions; that there is no conflict of interest of any kind; and that we followed all pertinent ethical and legal procedures and requirements. All financial sources are fully and clearly stated in the acknowledgements section. A signed document has been filed in the journal archives.

\section{ACKNOWLEDGMENTS}

The authors are gratefully to Frederick A. Sundberg (Museum of Northern Arizona, USA), who collected the material. The authors thanks the financial support provided by the project PRODEP UNISON-PTC-301: "Paleoecología de los ecosistemas marinos del
Cámbrico de Sonora, México: Bioestratigrafía, Paleobiogeografía y su relación con el cratón de Norteamérica". We also thank the Department of Geology at the University of Sonora, as well as the Instituto de Geología, UNAM, for the support given to carry out this research.

\section{RESUMEN}

Primer registro de Ubaghsicystis

(Eocrinoidea - Echinodermata) del Cámbrico

(Miaolingio, Wuliuan) de Sonora, México:

Consideraciones bioestratigráficas y paleoecológicas

Introducción: El presente trabajo constituye el primer registro en México de Ubaghsicystis Gil-Cid \& Domínguez-Alonso (Echinodermata-Eocrinoidea) procedente de la Formación El Gavilán, la cual aflora en el Cerro El Sahuaral, una nueva localidad del Cámbrico ubicada en la parte central del estado de Sonora, México. La Formación El Gavilán es una secuencia sedimentaria depositada en un ambiente marino de plataforma exterior, la cual consiste principalmente de lutita intercalada con caliza, conteniendo abundantes fósiles de invertebrados. Objetivo: El principal objetivo del presente trabajo de investigación es describir la especie Ubaghsicystis cf. $U$. segurae por primera vez para México, así como indicar las consideraciones bioestratigráficas y paleoecológicas. Métodos: Una sección estratigráfica compuesta fue medida para la Formación El Gavilán en Sonora central, donde muestras correspondientes a eocrinoides fueron colectadas, el material fue examinado en el Microscopio Leica MZ10. Resultados: La asociación biótica está conformada por esponjas reticulosas, chancellóridos (Chancelloria eros, Allonnia tintinopsis, Archiasterella sp.), hiolítidos, braquiópodos, trilobites (Quadragnostus depressa, Tonkinella valida, Elrathina sp.), y equinodermos (Ubaghsicystis cf. U. segurae). La asociación de trilobites confiere a estas rocas una edad del Cámbrico medio (Miaolingiano, Wuliuano), Subzona de Altiocculus, Zona de Ehmaniella. El material estudiado está constituido por placas aisladas y desarticuladas las cuales probablemente representen varios ciclos de placas de la teca, las cuales son asignadas a Ubaghsicystis cf. U. segurae. El género Ubaghsicystis ha sido documentado previamente en otras localidades del Cámbrico como Burgess Shale en Canadá y Los Barrios de Luna en España, para los cuales existen escasos registros. Conclusiones: La sucesión cámbrica de Sonora, donde ocurre Ubaghsicystis, formó parte del borde del cratón de Laurentia durante este período, el cual se localizaba cerca del Paleo Ecuador, donde se generaron las condiciones necesarias para una gran diversidad y abundancia de especies, incluyendo equinodermos.

Palabras clave: Eocrinoidea; Cámbrico; bioestratigrafía; paleoecología; México. 


\section{REFERENCES}

Almazán-Vázquez, E. (1989). El Cámbrico-Ordovícico de Arivechi, en la región centro oriental del estado de Sonora. Revista del Instituto de Geología UNAM, 8(1), 58-66.

Beresi, M.S., Buitrón-Sánchez, B., Cuen-Romero, F.J., \& Palafox, J.J. (2019). Escleritomos de Chancelloria eros y escleritos del Cámbrico medio (Serie 3, Piso 5) de Sonora central, México. Revista Mexicana de Ciencias Geológicas, 36(1), 54-63.

Bruguière, J.G. (1791). Tableau Encyclopédique et Méthodique, au les Vers Infusoires, les Vers Intestines, les Vers Mollusques (Vol. 7). Paris: Panckoucke.

Buitrón, B.E. (1992). Las rocas sedimentarias marinas del Paleozoico inferior de México y su contenido biótico. In J.C. Gutiérrez Marco, J. Saavedra, \& I. Rábano (Eds.), Paleozoico inferior de Ibero-América (pp. 193-201). Badajoz, Spain: Universidad de Extremadura.

Buitrón-Sánchez, B., Corona-González, N., Cuen-Romero F., Palafox-Reyes, J.J., \& Ramírez-Guerrero, G. (2016). Icnofósiles del Cámbrico Inferior de San José de Gracia, Sonora. Paleontología Mexicana, 5(1), 33-40.

Buitrón-Sánchez, B., Cuen-Romero F., Huerta-Ruiz, A., \& Montijo-González, A. (2017a). Hiolítidos del Cámbrico (Hyolitha) de San José de Gracia, Sonora, México. Consideraciones estratigráficas y paleogeográficas. Paleontología Mexicana, 6(1), 25-34.

Buitrón-Sánchez, B., Cuen-Romero F.J., Montijo-González, A., \& Beresi S.M. (2017b). El equinodermo Gogia granulosa (Echinodermata: Blastozoa) del Cámbrico temprano-medio en Sonora, México: paleoecología y paleogeografía. Revista de Biología Tropical, 65(1), 160-167.

Cooper, G.A., Arellano, A.R.V., Johnson J.H., Okulitch, V.J., Stoyanow. A., \& Lochman, C. (1952). Cambrian Stratigraphy and Paleontology near Caborca, northwestern Sonora, México. Smithsonian Miscellaneous Collections, 119, 1-184.

Cooper, G.A., Arellano, A.R.V., Johnson J.H., Okulitch, V.J., Stoyanow, A., \& Lochman, C. (1956). Geología y Paleontología de la región de Caborca, norponiente de Sonora. Ciudad de México: Universidad Nacional Autónoma de México, Instituto de Geología.

Cuen, R.F., Beresi, M.S., Montijo, A., Buitrón, B.E., Minjárez, I., De la O.M., \& Palafox, J.J. (2013). Chancelloriia Walcott, 1920 y Reticulosa Reid, 1958 del Cámbrico medio de San José de Gracia, Sonora, México. Boletín de la Sociedad Geológica Mexicana, $65,581-590$.

Cuen-Romero, F.J., Valdez-Holguín, J.E., Buitrón, B.E., Monreal, R., Sundberg, F., Montijo-González, A., \&
Minjarez-Sosa, I. (2016). Cambrian Stratigraphy of San José de Gracia, Sonora, Mexico: El Gavilán Formation, a new lithostratigraphic unit of middle Cambrian open shelf environment. Boletín de la Sociedad Geológica Mexicana, 68(3), 429-441.

Cuen-Romero, F.J., Valdez-Holguín, J.E., Buitrón-Sánchez, B.E., Monreal, R., Enríquez-Ocaña, L.F., Aguirre-Hinojosa, E., Palafox-Reyes, J.J. (2018). Trilobite-based biostratigraphy (Arthropoda-Trilobita) and related faunas of the Cambrian from Sonora, Mexico. Journal of South American Earth Sciences, 83, 227-236.

Cuen-Romero, F.J., Valdez-Holguín, J.E., Buitrón-Sánchez, B.E., Monreal, R., Enríquez-Ocaña, L.F., Hinojosa, E.A., Palafox Reyes, J.J. (2019). Paleoecology of Cambrian communities of central Sonora, Mexico: Paleoenvironmental and biostratigraphic considerations. Journal of South American Earth Sciences, 92, 631-645.

Danzos-Acuña, G.H. (2018). Bioestratigrafía del Cámbrico del Cerro El Sahuaral, Sonora, México: Paleoecología y Paleogeografia: Sonora, México (Master's thesis). Universidad de Sonora, Mexico.

Gil Cid, M.D., \& Domínguez Alonso, P. (2002). Ubaghsicystis segurae nov. gen. y sp., nuevo Eocrinoide (Echinodermata) del Cámbrico Medio del Norte de España. Coloquios de Paleontología, 53, 21-32.

González-León, C. (1986). Estratigrafía del Paleozoico de la Sierra del Tule, Noroeste de Sonora. Revista del Instituto de Geología UNAM, 6(2), 117-135.

Jaekel, O. (1918). Phylogenie und System der Pelmatozoen. Paläontologische Zeitschrift 3, 1, 1-128.

Liñán, E. (1996). Trilobites. Boletín de la SEA, 16, 45-56.

Lochman, C. (1948). New Cambrian Trilobite Genera from Northwest Sonora, Mexico. Journal of Paleontology, 22(4), 451-464.

McMenamin, M.A.S. (1987). Lower Cambrian trilobites, zonation, and correlation of the Puerto Blanco Formation, Sonora, Mexico. Journal of Paleontology, 61(4), 738-749.

Nardin, E., Almazán-Vázquez, E., \& Buitrón-Sánchez, B.E. (2009). First report of Gogia (EocrinoideaEchinodermata) from the Early-Middle Cambrian of Sonora (México), with biostratigraphical and paleoecological comments. Geobios, 42, 233-242.

Noriega-Ruiz, H.A. (2019). Litofacies, microfacies y biofacies del Cámbrico del área El Sahuaral, Sonora central: consideraciones paleoecológicas y paleogeográficas (Master's thesis). Universidad de Sonora, Mexico.

Noriega-Ruiz, H. A., Cuen-Romero, F. J., Enríquez-Ocaña, L. F., Sundberg, F. A., Monreal, R., Varela-Romero, 
A., Palafox-Reyes, J. J., \& Grijalva-Noriega, F. J. (2020). Cambrian stratigraphy (Series 2 to Miaolingian) of the El Sahuaral area in central Sonora, Mexico: Biostratigraphic implications. Journal of South American Earth Sciences, 103(2020), 102797. https:// doi.org/10.1016/j.jsames.2020.102797

Rasetti, F. (1951). Middle Cambrian Stratigraphy and faunas of the Canadian Rocky Mountains. Smithsonian Miscellaneous Collections, 116, 1-277.

Robison, R.A. (1976). Middle Cambrian Eocrinoids from western North America. Journal of Paleontology, 39(3), 355-364.

Sprinkle, J. (1973). Morphology and evolution of the blastozoan echinoderms. Cambridge: Harvard University Museum of Comparative Zoology, 283 pp.

Stewart, J.H., Amaya-Martínez, R., \& Palmer, A.R. (2002). Neoproterozoic and Cambrian strata of Sonora, Mexico: Rodinian supercontinent to Laurentian Cordilleran margin. Special Papers-Geological Society of America, 365, 5-48.
Stewart, J.H., McMenamin, A.S., \& Morales-Ramirez, J.M. (1984). Upper Proterozoic and Cambrian Rocks in the Caborca Region, Sonora, México. Physical Stratigraphy, Biostratigraphy, Paleocurrent Studies and Regional Relations. U.S. Geological Survey Professional Paper, 1309, 36.

Sumrall, C.D., \& Zamora S. (2015). A columnal-bearing eocrinoid from the Cambrian Burgess Shale (British Columbia, Canada). Journal of Paleontology, 89(2), 366-368.

Sundberg, F.A. (1994). Corynexochida and Prychopariida (Trilobita, Arthropoda) of the Ehmaniella Biozone (Middle Cambrian), Utah and Nevada. Contributions in Science, 446, 137.

Vega-Granillo, R. (1996). Geología de la Sierra de Mazatán. Boletín del Departamento de Geología, 13, 89-102.

Zamora, S., Clausen, S., Álvaro, J.J., \& Smith A.B. (2010). Pelmatozoa echinoderms as colonizers of carbonate firmgrounds in mid-Cambrian high-energy environments. Palaios, 25, 764-768. 